\title{
Farming Families and Climate Change Issues in Niger Delta Region of Nigeria: Extent of Impact and Adaptation Strategies
}

\author{
Michael E. Ikehi1 ${ }^{*}$, Francis M. Onu1, Florence O. Ifeanyieze1, Patrick S. Paradang2 \\ ${ }^{1}$ Agricultural Unit, Department of Vocational Teacher Education, University of Nigeria, Nsukka, Nigeria \\ ${ }^{2}$ Department of Agriculture Education, Federal College of Education, Pankshin, Nigeria \\ Email: ${ }^{*}$ ikehidon1@yahoo.com
}

Received 6 August 2014; revised 19 September 2014; accepted 21 October 2014

Copyright (C) 2014 by authors and Scientific Research Publishing Inc.

This work is licensed under the Creative Commons Attribution International License (CC BY). http://creativecommons.org/licenses/by/4.0/

(c) $\underset{\mathrm{EY}}{\mathrm{EY}}$ Open Access

\section{Abstract}

The study focused on the impacts of climate change on the farmer and the farming families in Niger Delta Region of Nigeria. The study specifically evaluated the perceived resultant situations attributed to climate change to determine the extent of impacts of climate change on the farmer and the farming families and also explored adoptable strategies for coping with the situations. The study adopted descriptive survey research design. Two research questions and two hypotheses guided the study. The population for the study was 246,909 respondents made up of farmers and extension workers who are registered with the State Ministries of Agriculture. Out of the nine Niger Delta states, Bayelsa and Delta states were randomly chosen for the study. Proportionate stratified random sampling technique was used to select a sample size of 5,038 respondents. Structured questionnaire and interview were used to collect data. The instruments were validated by three experts. Cronbach Alpha method was used to determine the internal consistency of the questionnaire items which yielded a coefficient of 0.81 . The Statistical Product and Service Solutions (SPSS v 20.0) was employed for data analysis. The statistical tools used for data analysis were weighted mean to answer research questions and standard deviation to validate the closeness of the respondents from the mean and from each other in their responses while t-test was used to test the null hypotheses. The findings of the study revealed that the extent of impacts of climate change on farmers and the farming families in Niger Delta region of Nigeria are moderate. Findings further revealed that climate change has led to increased poverty level and raised cost of production (input and labour cost) as indicated by the farmers. The study recommends that farmers in the region should be encouraged by providing incentives and subsidizing inputs for them by Federal and State governments as well as other non-governmental organizations, as this will go a long way in improving production especially as most farmers agree to continue cultivation even with the observed impacts.

\footnotetext{
"Corresponding author.
}

How to cite this paper: Ikehi, M.E., Onu, F.M., Ifeanyieze, F.O. and Paradang, P.S. (2014) Farming Families and Climate Change Issues in Niger Delta Region of Nigeria: Extent of Impact and Adaptation Strategies. Agricultural Sciences, 5, 11401151. http://dx.doi.org/10.4236/as.2014.512124 


\section{Keywords}

\section{Climate Change, Farming Families, Impacts, Flooding, Sea Level Rise, Adaptation, Temperature}

\section{Introduction}

The environmental changes attributable to climate change are known to have direct and/or indirect effects on farmers thus on agricultural production in any region. Agriculture, for its numerous ecosystem services, has been an important component of human society. Agriculture generates revenue for the government at the federal, state and local levels and as well serves as a means of livelihood by providing employment for farmers, marketers and processors of agricultural products. Like many countries, agriculture is a major sector of Nigeria's economy, engaging over 70\% of labour force and contributing about $40 \%$ to Gross Domestic Product [1]. Agricultural production processes greatly rely on climate, thus a change in its composition is bound to have effects on the sector. Climate change has been a global issue affecting various agricultural production processes, including the producers: the farmers and their families. Climate change is the complete variation of the average state of the atmosphere over time, ranging from decades to millions of years in a region or across the entire globe, and can be caused by processes internal to the earth, external forces from space or anthropological activities [2]. In recent time, especially in the context of environmental policy, climate change has often been referred to as the noticeable variation in environmental and atmospheric composition attributed to human activities [3]. Climate change in the context of this study refers to the variation in the statistical distribution of average weather conditions over a prolonged period of time in any region of the world, such as the Niger Delta region of Nigeria.

Niger Delta region of Nigeria is densely populated and occupies about $12 \%$ of the total land mass of Nigeria with a land area of about $70,000 \mathrm{~km}^{2}$ out of which 2,370 $\mathrm{km}^{2}$ consist of rivers, creeks and estuaries, while stagnant swamp covers about $8,600 \mathrm{~km}^{2}$ [4]. The region is endowed with great potentials for high productive and profitable agriculture [5]. The region is divided into drier landward part where crop farming is the major agricultural activity and the seaward part (riverine and swampy areas) which is characterized by extensive creeks and water bodies where fishing and aquaculture replaces crop farming as the dominant aspect of the rural economy [6]. Economic activities of communities in the region are either land-based or water-based to include collection and processing of palm fruits, crop and animal farming, fishing and fish farming, forest resources utilization (such as game and raffia) and trading of agricultural goods [7]. The region occupies greater area of Nigeria's most fertile land suitable for the cultivation of crops such as cassava, palm tree, rubber, yam, and many other crops while the availability of water bodies makes aquaculture (like fish farming) feasible [8]. The major agricultural produce in the region are cassava, cocoa, maize, melon, okra, palm oil, rubber and yam, in addition to domestication of animals such as fishes, goats, pigs, poultry, sheep, snail and rabbit. The topical alteration in climate has become significant for worldwide discussion as it is likely human-induced.

The major human related cause of climate change is the increase of Green House Gases (GHG) in the atmosphere resulting from gas flaring, fossil burning and deforestation arising from clearing of land for agricultural and industrial uses, in addition to other human activities that have led to increased concentrations of GHG especially carbon IV oxide $\left(\mathrm{CO}_{2}\right)$ [3] [9]. The two primary sources of GHG emission are combustion of fuels and flaring of the natural gas, which is extracted along with crude oil [10]. In 2009, the average $\mathrm{CO}_{2}$ emission in Nigeria was 74.14 million metric tons, which increased to 80.51 million metric tons and was predicted to drastically increase in the near future due to rising demand for products from crude oil [11]. Anthropological activities have sped up climate change in recent time leading to the persisting impacts on agriculture and livelihoods in communities. For example, the Niger Delta region is reported to have over 123 gas flaring sites, making Nigeria one of the highest emitters of GHG in Africa [12]. Nigeria accounts for roughly one-sixth (1/6) of worldwide gas flaring: Nigeria flares about $75 \%$ of her gas [13] and all take place in the Niger Delta region. Some 45.8 billion kilowatts of heat are discharged into the atmosphere of the Niger Delta, from flaring 1.8 billion cubic feet of gas every day [14]. Between 1970 and 1986, about 125.5 million cubic meters of gas was produced in the Niger Delta region of which about 102.3 (81.7\%) million cubic meters were flared [13]. The flares, due to the existence of oil industries in the region, have apparently contributed to the increase of GHG which alters climatic composition over time. The main effect of climate change is the increased average temperature which causes a 
variety of secondary effects [3]. The secondary effects caused by increased temperature include, change in precipitation affecting rainfall, rise in sea level leading to coastal erosion and flooding, altered patterns of agricultural/cultural practices, extreme weather events and expansion of range of tropical diseases [15]. These secondary effects have affected the world in varying degree of impacts in different regions.

Drought, floods, severe weather and other effects of climate change have begun to threaten communities in many parts of the world. Sickness and death due to diseases such as diarrhea are projected to increase in East, South, and Southeast Asia as a result of expected alteration in the hydrological cycle and decrease in freshwater availability particularly in large river basins [16]. Increased flooding from overflowing seas and rivers, threatens coastal areas, especially heavily populated delta regions in South, East, and Southeast Asia [16]. Sea level rise is projected to increase risk of flooding, displacement of people, salinization of drinking water sources and coastal erosion in low-lying regions in America [17]. As the environment is being affected by altered climate which affects natural sources of livelihood, people especially the indigent who cannot cope with the drastic changes may have to migrate in search for fairer and better opportunities. Estimates of "climate change migrants" range from 200 million to 1 billion people by 2050 [18].

Africa is one of the most vulnerable continents to face climate change because of multiple existing stress and low adaptive capacity [19]. Sea level rise is projected to worsen inundation, storm surge, erosion, and other coastal hazards in the continent, and these effects would threaten vital infrastructure, settlements and facilities that support the livelihood of isolated communities [19]. In many African countries, other factors already threatening human health such as malaria may increase as altered weather conditions could favour the proliferation of carrier agents [20]. By 2020, between 75 and 250 million people are projected to be exposed to increased water stress and by 2050, between 350 million and 600 million people in Africa are projected to experience increased water stress due to climate change [20]. Niger Delta like other deltas is recognized as vulnerable to climate change due to its low-lying area.

Climate change in the Niger Delta region has led to flooding, scorching temperature, change in rainfall pattern, coastal erosion, occasions of acid rain and increased water salination. Flooding in the region (between July and October 2012) forced rivers to overflow their banks and submerged hundreds of thousands of acres of farmland, led to destruction of buildings and blockage of transportation routes in the region [21]. The cost of managing the land for cultivation, cure for diseases and pests control in animal, crop and fish production has increased as a result of climate change, and is affecting the social and economic wellbeing of farmers in the region. The wellbeing of the farmer and the farming families is as important as the production process and the agricultural produce. Climate change affects not just agricultural produces but also the farmers and their families as well as the environment they dwell, leading to decline in performance thus reduced yields. Variation in temperature and humidity alters pest and disease movement and favours the risk of invasion thus could increase the emergence of health-related hazards for the farmer and his family. Frequent natural disasters like floods, ocean and storm surges damage sources of livelihood and also causes harm to farmland, post-harvest activities, life and property [9] [22].

Extreme storm events are likely to increase failure of floodplain protection as well as damage urban drainage and sewage systems [23]. Increased heat causes discomfort for the farming family while intense heat wave leads to electricity blackout [20]. While the farming families in the region still engage in agricultural activities like crop farming and fishing, they work more with little in return. Their farming and fishing have been impaired in recent times by the deplorable state of the environment as a result of altered and unfavourable climate [9]. According to the author, due to the degradation of their immediate environment, the local farmers can no longer engage in sustainable production leading to risen poverty level in the region among the locals. Change in climate affects crops, livestock, forestry, and fishery in various ways bearing direct impacts on the farmer and his family. Many people in the Niger Delta whose source of livelihood once depended on natural sectors such as, farming and fishing are now changing their means of livelihood. Change in the farming occupation will have adverse effects on agricultural sector in the region and the nation as a whole. Continued degradation of land and water as a result of climate change in the region will affect the major agricultural produce in the region, thus increasing hardship for the farmer and his family. However, the capacity to adapt can influence how climate change affects individuals, communities, regions, countries and the global population.

The potential to adjust in order to minimize negative impacts and maximize any benefits from climate change is known as adaptive capacity [24]. As speculated by Lemke [2] dry regions will become even drier while wet ones will receive more rains. Climate change affects every region but the degree and nature of impacts resulting 
from the phenomenon will differ from region to region and will depend on the capacity of the different regions to adapt to the changes. Climate change adaptation is an understanding of how individuals, groups and natural systems prepare for and respond to changes in climate or their environment to reduce vulnerability [24]. It is the adjustment in natural or human systems in response to actual or expected climate stimuli or their effects to moderate harm and increase benefits from available opportunities [3]. Climate change adaptation in this study involves taking action to minimize the impacts of weather variation while exploring new openings that may be beneficial. The type of adaptation measures adopted depends on the nature and extent of impacts, social resilience and economic capacity of the region to deal with the observed and expected changes. Increasing the capacity to adapt reduces vulnerability to the effects and a successful adaptation can reduce vulnerability by building on and strengthening existing strategies.

Developed and developing countries alike are working hard to find solutions to the effects of climate change, as the impacts vary in extent and nature. In order to address the resulting impacts, adaption practices should lay emphasis on community interest to encourage sustainable development. It is suggested that adaptation strategies will be more successful if they are identified and presented to local users for vetting to ensure their consistency with local priorities, norms, goals and institutions [25]. Community-based adaptation has become an important term in the climate change debate [9]. It recognizes the fact that environmental knowledge and resilience to climate change lay within societies and cultures [24]. Furthermore, an understanding of how communities cope with environmental changes is important when developing community-based adaptation projects to mitigate the effects of climate change for the local farmers and their families. The goal of community-based adaptation is to increase climate change resilience of communities by enhancing their capacity to cope with climate related issues such as less predictable rainfall patterns, frequent droughts, stronger heat wave, invasion of diseases and weather hazards of unprecedented intensity [24]. Staying informed about climate change and supporting efforts to slow its progress are things necessary to be done. The climate is already changing because of the existing build-up of GHGs in the atmosphere, therefore it is important to prepared for and adapt to those changes. While actions now to reduce emissions is critical, the existing build-up of GHG concentrations means that some effects of climate change are inevitable in this and coming decades and planning must start now on adapting families, production processes, economy and the society to these changes.

Strategies aimed at adapting crop farming to climate change include adjusting planting and harvest dates, changing varieties grown, increasing water, fertilizer, herbicide and pesticide use and enhancing drainage systems [26]. Changes in land-use and in crop and livestock management practices will have to take place, such as (a) change in cultivated land area, (b) changing crop and animal types, (c) rearing animal species that can withstand higher thermal changes and growing crops that are drought and flood tolerant, (d) change in farm siting, (e) use of irrigation and improved fertilizer use efficiency to counter the effects of droughts (periodic water stress) and low soil fertility conditions due to leaching and erosion resulting from coastal flooding, (f) improved control mechanisms for insect pests and diseases associated with weather change (g) improvement in soil management practices to reduce surface runoff and soil erosion (h) establishment and creation of food grain reserves at farm and community levels for safe-keeping and storage of harvested produce, and (i) intercropping arable crops with trees to benefit from improved micro-climate as well as tree products and services [27]. Others include diversifying into multiple and mixed crop-livestock systems, switching from crop to livestock farming, switching from fishing to fish farming, switching from rain-fed to irrigated farming and making ridges across farms [23]. Some suggested adaptation practices also includes construction of foot-bridges across road tracks, raising of barriers/dikes in response to sea level rise/flood, use of mulching material for crops and shades for animal houses to reduce heat, using improved varieties/breeds to ensure survival of cultivated and reared crops and animals, switching to mechanized farming to reduce hard labour as well as the involvement of technology in production processes [3] [9] [24]. Successful implementation of these strategies will improve production and favour the farmer and the farming families. The farmers are complaining of sweeping changes they could not comprehend as their previous knowledge could not serve them competently. It is thus necessary to determine the extent to which climate change has impacted on the farmers and their families in the region and as well important to test the suggested adaptation strategies for conformity in the locality. The guided opinion of the extension workers (who are trained to provide updated information to the farmers) and the farmers in the region has helped the study to answer the following research questions and test the stated hypotheses:

Research Questions:

1. To what extent has climate change impacted on farmers and the farming families in the Niger Delta region? 
2. What strategies can be adopted to alleviate the impacts of climate change on agricultural production to favour farmers and the farming families in the Niger Delta region of Nigeria?

Hypotheses:

$\mathrm{H}_{01}$ : There is no significant difference in the mean ratings of farmers and extension workers on the extent to which climate change has impacted on farmers and the farming families in the Niger Delta region.

$\mathrm{H}_{02}$ : There is no significant difference in the mean ratings of farmers and extension workers on the strategies that can be adopted to alleviate the impacts of climate change on agricultural production to favour farmers and the farming families in the Niger Delta region of Nigeria.

\section{Materials and Methods}

The study was carried out to determine the extent to which climate change has impacted on the farmer and the farming families in agricultural production in Niger Delta region of Nigeria. The study also presented available adaptation strategies as being suggested by various authors for testing of conformity with rural farmers, following the view that environmental knowledge and resilience to climate change lay within societies and cultures. The study which span from November 2012 to May 2014 adopted descriptive survey research design and was carried out in the Niger Delta region of Nigeria. The region which is located in the Southern part of Nigeria is made up of 9 states, namely: Abia, Akwa-Ibom, Bayelsa, Cross River, Delta, Edo, Imo, Ondo and River. Bayelsa and Delta were randomly chosen for the study. The population for the study was 246,909 , made up of farmers $(67,551+179,256=246,807)$ and extension agents $(12+90=102)$ who are registered with the State Ministries of Agriculture in (Bayelsa + Delta) states, respectively. The farmers and the extension agents were involved in the study because they have experienced the perceived impacts of climate change and bear firsthand information for answering the research questions of this study.

Proportionate stratified random sampling technique was used to select 2 percent $(4,936)$ of the farmers from each local government areas (strata) in both state, while all the extension agents (102) from both state were utilized due to their manageable size. Thus the total sample size for the study was 5,038 respondents. The instruments for data collection were structured questionnaire and interview developed from literature reviewed for the study. The use of the questionnaire was to generate quantifiable data while the interview was to enable the respondents to elaborate their view on each item and as well to state the nature of perceived impacts. The instruments were divided into two sections, each section corresponding to the research questions of the study. Each item in the first section of the questionnaire instrument had a four point response options of High Extent (HE), Moderate Extent (ME), Low Extent (LE) and No Extent (NE) while the second section had Strongly Agree (SA), Agree (A), Disagree (D) and Strongly Disagree (SD) and were all weighted 4, 3, 2 and 1 respectively. Three experts validated the instruments: one from Agricultural Development Programme (ADP) at Delta state Ministry of Agriculture and Natural resources and two lecturers from Agricultural Education Unit at the Department of Vocational Teacher Education, University of Nigeria, Nsukka. The reliability of the questionnaire instrument was established using Cronbach Alpha method and a co-efficient of 0.81 was obtained. The researchers with the help of 5 research assistants went around the geographical area of the study and physically administered and collected the completed instruments from contact respondents (see Appendix A) who were available to respond to the instruments. The administration of the instrument was done in bit with the researchers and the assistants covering a carved out area within a period of time through repeated visits. Out of the 5,038 copies of both instruments administered, 3,214 copies (representing about 64 percent of the total copies) were successfully retrieved. However, only 2,922 copies were duly completed and found useful for data analysis. The Statistical Product and Service Solutions (SPSS v 20.0) was employed for data analysis. The statistical tools used for data analysis were weighted mean to answer research questions and standard deviation to validate the closeness of the respondents from the mean and from each other in their responses while t-test was used to test the null hypotheses. The observation for the items for each research question was explained using real limit of number of the mean as follows:

\begin{tabular}{ccc}
\hline Response Option & Mean Weight & Real Limit of Number \\
\hline High Extent (HE)/Strongly Agree (SA) & 4 & $3.50-4.00$ \\
Moderate Extent (ME)/Agree (A) & 3 & $2.50-3.49$ \\
Low Extent (LE)/Disagree (D) & 2 & $1.50-2.49$ \\
No Extent (NE)/Strongly Disagree (SD) & 1 & $0.50-1.49$ \\
\hline
\end{tabular}


In taking decisions for research question 1; any item with a mean value ranging from 3.50 - 4.00, 2.50 - 3.49 or $1.50-2.49$ was interpreted as high, moderate or low extent of impact, respectively while any item with a mean value below 1.50 (0.50 - 1.49) was interpreted as no extent, meaning climate change has no perceived impact on the item. With reference to research question 2; any item with a mean value ranging from $3.50-4.00$, 2.50 - 3.49 or 1.50 - 2.49 was regarded as strongly agreed, agreed or disagreed respectively, while any item with a mean value ranging from $0.50-1.49$ (mean values below 1.50 ) was regarded as strongly disagreed. For the hypotheses:

If $\quad p \leq a$ value at $t$ value, then there is significant difference (S) in the compared means thus the decision was to reject the stated null hypothesis.

But if

$p \geq a$ value at $t$ value, then there is no significant difference (NS) in the compared means thus the decision was to not reject but uphold the stated null hypothesis.

Where $\quad p$ is the *Sig (2-tailed) value of t-calculated, $a=0.05$ (significant level) and, $t$ is the t-test score (t-calculated).

The structured interview was analyzed qualitatively.

\section{Results}

The results of the study is presented in Tables 1 and 2, and discussed according to research question and hypothesis.

Research Question 1: To what extent has climate change impacted on farmers and the farming families in the Niger Delta region?

Average response of the farmers indicated that the impacts of climate change on two items (No. 10 and 14) is to a high extent (HE) as their mean values fell between 3.50 - 4.00 real limit of number. Impacts on nine items (No. 3, 4, 6, 9, 12, 13 and 15 - 17) were to a moderate extent (ME) as their means were within 2.50 and 3.49, while impacts were to a low extent (LE) on four items (No. 5, 7, 8 and 11) as their means ranged from 1.50 to 2.49. Two items (No. 1 and 2) were not affected by climate change as their mean values were below 1.50 (0.50 1.49) thus climate change had no extent (NE) of impact. Responses from extension workers revealed that impacts were to a high extent (HE) on one item (No. 14) as its mean value was 3.53 which fell within 3.50 - 4.49. Impacts were to a moderate extent (ME) on eleven items (No. 3 - 10,12, 13 and 15) as their means fell between 2.50 and 3.49. Four items (No. 1, 2, 16 and 17) experienced low extent of impact as their means values were within 1.50 and 2.49 while one item (No. 11) was not affected by climate change as its mean was 1.09 which was below 1.50 (0.50 - 1.49) thus climate change impacts were insignificantly.

On average response of farmers and extension workers, one item (No. 14) was highly (HE) impacted as its mean value was 3.74 which fell within 3.50 - 4.00 real limit of number. Impacts were to a moderate extent (ME) on fourteen items (No. 3 - 10, 12, 13 and 15 - 17) as their means fell within 2.50 and 3.49. Three items (No. 1, 2 and 11) had low extent of impact as their means were between 1.50 and 2.29. In summary, the extent of impact of climate change on farmers and the farming families in the Niger Delta region of Nigeria is to a moderate extent (ME) as indicated by the average mean response (2.68) of both farmers and extension workers. The standard deviation of all the items ranged from 0.11 - 1.54 with an average value of 1.03; indicating that the respondents were close to the mean and to one another in their responses.

The information from the structured interview complemented the data from the questionnaire as presented on Table 1. The respondents explained that climate change has impacted noticeably (though not to a high or low extent but) to a moderate extent on the activities of the farming families in the region. The nature of the impact was revealed to be negative. As reported, inside the buildings are becoming hotter causing heat stress for the residents, scorching of seedlings and frequent flooding destroying farm lands in the region affecting the economy of the local farmers which has led to increasing difficulty in making ends meet.

\subsection{Hypothesis 1}

There was no significant difference (S) in the opinions of farmers and extension workers in twelve items (No. 1 - 5, 7 - 9, 11 - 13 and 15) as indicated in the data presented on Table 1. However, Table 1 revealed a no-significant (NS) difference in five items (No. 6, 10, 14, 16 and 17). The cluster value indicated that the difference in 
Table 1. Mean ratings, standard deviation and t-test scores of respondents on the extent to which climate change has impacted on the farmer and the farming families in the Niger delta region of Nigeria.

\begin{tabular}{|c|c|c|c|c|c|c|c|c|c|c|c|c|}
\hline \multirow{4}{*}{$\begin{array}{l}\mathrm{S} / \mathrm{N} \text { : Effects on the farmer and the } \\
\text { farming families }\end{array}$} & \multicolumn{6}{|c|}{$\mathrm{n}_{1}=2829$} & \multicolumn{3}{|c|}{$\mathrm{n}_{2}=93$} & \multicolumn{3}{|c|}{$\mathrm{N}_{\mathrm{T}}=2922$} \\
\hline & \multicolumn{6}{|c|}{ Respondents } & \multirow{2}{*}{\multicolumn{3}{|c|}{ Avg. Resp. }} & \multirow{2}{*}{\multicolumn{3}{|c|}{$\mathbf{H}_{01}$}} \\
\hline & \multicolumn{3}{|c|}{ Farmers } & \multicolumn{3}{|c|}{ Ext. Workers } & & & & & & \\
\hline & $\bar{X}$ & SD & Dec & $\bar{X}$ & SD & Dec & $\bar{X}$ & SD & Dec & $t$ & *Sig & $\mathbf{R}$ \\
\hline 1. Water availability for irrigation & 1.17 & 1.09 & $\mathrm{NE}$ & 2.09 & 1.18 & LE & 1.63 & 1.14 & LE & 2.253 & 0.025 & $\mathrm{~S}$ \\
\hline 2. Drying up of ponds and streams & 1.19 & 1.15 & NE & 2.07 & 0.98 & LE & 1.63 & 1.07 & LE & 3.752 & 0.000 & S \\
\hline 3. Pollution of clean water sources & 3.42 & 0.89 & ME & 3.32 & 1.01 & ME & 3.37 & 0.95 & ME & 6.413 & 0.000 & S \\
\hline 4. Increased risk of sickness & 2.52 & 1.11 & ME & 3.07 & 1.13 & ME & 2.80 & 1.12 & ME & -3.917 & 0.000 & S \\
\hline 5. Spread of disease & 2.38 & 0.97 & LE & 3.04 & 1.06 & ME & 2.71 & 1.02 & ME & -5.733 & 0.000 & $\mathrm{~S}$ \\
\hline 6. Damage to buildings & 2.70 & 1.19 & ME & 2.94 & 1.16 & ME & 2.82 & 1.18 & ME & 1.339 & 0.120 & NS \\
\hline 7. Damage to roads and bridges & 2.41 & 0.97 & LE & 3.02 & 1.09 & ME & 2.72 & 1.03 & ME & 6.087 & 0.000 & $\mathrm{~S}$ \\
\hline 8. Roof damage by acid rain & 2.15 & 1.00 & $\mathrm{LE}$ & 2.96 & 1.20 & ME & 2.56 & 1.10 & ME & -8.139 & 0.000 & $\mathrm{~S}$ \\
\hline 9. Drainage system damage & 2.87 & 1.12 & ME & 3.02 & 1.00 & ME & 2.95 & 1.06 & ME & 6.159 & 0.007 & S \\
\hline $\begin{array}{l}\text { 10. Difficulty in making ends meet } \\
\text { (Poverty level) }\end{array}$ & 3.51 & 1.15 & $\mathrm{HE}$ & 3.22 & 1.01 & ME & 3.37 & 1.08 & ME & 0.817 & 0.570 & NS \\
\hline 11. Loss of live (mortality rate) & 2.41 & 0.95 & $\mathrm{LE}$ & 1.89 & 1.23 & $\mathrm{NE}$ & 2.15 & 1.09 & LE & 2.699 & 0.000 & S \\
\hline $\begin{array}{l}\text { 12. Change in rainfall pattern affecting } \\
\text { historical patterns of cultivation }\end{array}$ & 2.54 & 1.08 & $\mathrm{ME}$ & 2.94 & 1.11 & ME & 2.74 & 1.10 & ME & 9.195 & 0.000 & S \\
\hline $\begin{array}{l}\text { 13. Hotter environment leading to heat } \\
\text { stress }\end{array}$ & 2.58 & 0.99 & ME & 3.04 & 0.94 & ME & 2.81 & 0.97 & ME & 4.591 & 0.000 & $\mathrm{~S}$ \\
\hline $\begin{array}{l}\text { 14. Flooding of houses, farmland and } \\
\text { animal houses }\end{array}$ & 3.95 & 0.11 & HE & 3.53 & 0.74 & $\mathrm{HE}$ & 3.74 & 0.43 & $\mathrm{HE}$ & 0.508 & 0.611 & NS \\
\hline $\begin{array}{l}\text { 15. Nature and difficulty of work done } \\
\text { on the farm }\end{array}$ & 2.75 & 0.97 & $\mathrm{ME}$ & 2.93 & 1.20 & ME & 2.84 & 1.09 & ME & -6.915 & 0.000 & $\mathrm{~S}$ \\
\hline $\begin{array}{l}\text { 16. Cost of production (input and labour } \\
\text { cost) }\end{array}$ & 3.39 & 0.76 & ME & 2.26 & 1.54 & LE & 2.83 & 1.15 & ME & 1.953 & 0.144 & NS \\
\hline 17. Net profit from farming & 2.94 & 0.92 & ME & 2.34 & 1.08 & LE & 2.64 & 1.00 & ME & 1.786 & 0.163 & NS \\
\hline Cluster Value & 2.64 & 0.97 & ME & 2.80 & 1.10 & ME & 2.72 & 1.03 & ME & 1.344 & 0.096 & NS \\
\hline
\end{tabular}

Note: Dec-Decision; Avg. Resp.—Average Response; High Extent (HE = 3.50 - 4.00); Moderate Extent (ME = 2.50 - 3.49 ); Low Extent (LE = 1.50 - 2.49); No Extent (NE = 0.50 - 1.49); $\mathrm{p}$ = *Sig (2-tailed); R—Remark; NS—Non Significant; S—Significant.

their opinions was not significant (NS). The null hypothesis of no significant difference of the items with remark NS was upheld as $p$-value is greater than the $a$-value $(p \geq a)$ at the t-calculated value of the items.

At the cluster level, $p=0.096$ and $t=1.344$ while $a=0.05$. Thus the null hypothesis $\left(\mathrm{H}_{01}\right)$ of no significant difference was not rejected but upheld as $p \geq a$.

Research Question 2: What strategies can be adopted to alleviate the impacts of climate change on agricultural production to favour farmers and the farming families in the Niger Delta region of Nigeria?

Farmers strongly agreed (SA) to two items (No. 19 and 20, as their mean values were 3.62 and 3.51 respectively which fell within 3.50 - 4.00 real limit of numbers) as suitable adaptation strategies for coping with the impacts of climate change in the region. As indicated in Table 2, farmers agreed (A) to twenty-one items (No. 1 - 7, 9 - 11, 13, 14, 17, 18 and 21 - 26) as their means were between 2.50 and 3.49, while disagreeing (D) to five items (No. 8, 12, 15, 16 and 28) as their means fell within 1.50 and 2.49. The extension workers strongly agreed (SA) to one item (No. 20) as a coping strategy, as its mean value was 3.81 which fell between 3.50 and 4.00 . The extension workers agreed to the remaining twenty-seven items (No. 1 - 19 and 21 - 28) as copying strategies with their means ranging from 2.50 to 3.49 .

On average response of farmers and extension workers, one item (No.20) was strongly agreed (SA) to as a coping strategy having an average mean of 3.66 which fell between $3.50-4.49$ real limit of number, while they agreed (S) to twenty-four items (No. 1 - 7, 9 - 11, 13 - 19 and 21 - 26) as their means ranged from 2.50 to 3.49. Average response of the farmers and the extension workers however disagreed (D) to the remaining three items (No. 8, 12 and 28) as their means fell within 1.50 and 2.29. In summary, for the coping strategies as indicated in Table 2, one item was strongly agreed to, twenty-four items were agreed to while three items were disagreed to as coping strategies by the respondents. 
Table 2. Mean ratings, standard deviation and t-test scores of respondents on the strategies that can be adopted to alleviate the impacts of climate change on agricultural production to favour the farmer and the farming families in the Niger delta region of Nigeria.

\begin{tabular}{|c|c|c|c|c|c|c|c|c|c|c|c|c|}
\hline \multirow{4}{*}{ S/N: Suggested Adaptation Strategies } & \multicolumn{6}{|c|}{$\mathrm{n}_{1}=2829$} & \multicolumn{3}{|c|}{$\mathrm{n}_{2}=93$} & \multicolumn{3}{|c|}{$\mathrm{N}_{\mathrm{T}}=2922$} \\
\hline & \multicolumn{6}{|c|}{ Respondents } & \multirow{2}{*}{\multicolumn{3}{|c|}{ Avg. Resp. }} & \multirow{2}{*}{\multicolumn{3}{|c|}{$\mathbf{H}_{02}$}} \\
\hline & \multicolumn{3}{|c|}{ Farmers } & \multicolumn{3}{|c|}{ Ext. Workers } & & & & & & \\
\hline & $\bar{X}$ & SD & Dec & $\bar{X}$ & SD & Dec & $\bar{X}$ & SD & Dec & $t$ & *Sig & $\mathbf{R}$ \\
\hline $\begin{array}{l}\text { 1. Using improved crop varieties and } \\
\text { animal breed }\end{array}$ & 3.16 & 0.98 & A & 3.17 & 0.89 & A & 3.17 & 0.89 & A & 0.885 & 0.151 & NS \\
\hline 2. Change planting/stocking time & 2.89 & 0.92 & A & 3.35 & 0.79 & A & 3.12 & 0.86 & A & 1.598 & 0.111 & NS \\
\hline $\begin{array}{l}\text { 3. Use of mulching materials for crops } \\
\text { and shades for animals }\end{array}$ & 3.25 & 1.10 & A & 3.06 & 1.07 & A & 3.16 & 1.09 & A & 6.413 & 0.000 & $\mathrm{~S}$ \\
\hline 4. Using early maturing plants/animals & 2.70 & 0.88 & A & 2.96 & 1.15 & A & 2.83 & 1.02 & A & 2.341 & 0.020 & $\mathrm{~S}$ \\
\hline $\begin{array}{l}\text { 5. Using nursery for transplantable } \\
\text { crops }\end{array}$ & 2.75 & 1.10 & A & 2.60 & 1.29 & A & 2.68 & 1.20 & A & 3.585 & 0.000 & $\mathrm{~S}$ \\
\hline 6. Mix cropping & 2.77 & 0.98 & A & 3.13 & 1.01 & A & 2.95 & 1.00 & A & 3.580 & 0.000 & $\mathrm{~S}$ \\
\hline 7. Practicing land and/or crop rotation & 2.56 & 1.00 & A & 2.96 & 1.08 & A & 2.76 & 1.04 & A & 9.494 & 0.000 & $\mathrm{~S}$ \\
\hline $\begin{array}{l}\text { 8. Planting deeper than the usual } \\
\text { planting depth to prevent scorching }\end{array}$ & 1.92 & 0.99 & $\mathrm{D}$ & 3.01 & 1.08 & A & 2.47 & 1.04 & $\mathrm{D}$ & 1.692 & 0.072 & NS \\
\hline $\begin{array}{l}\text { 9. Intensive fertilizer/manure } \\
\text { application for crop production }\end{array}$ & 2.72 & 1.06 & A & 2.99 & 0.92 & A & 2.86 & 0.99 & A & 2.229 & 0.026 & $\mathrm{~S}$ \\
\hline 10. Change of harvesting date & 2.93 & 1.03 & A & 3.13 & 0.98 & A & 3.03 & 1.01 & A & 4.993 & 0.000 & S \\
\hline 11. Expansion of farming land & 2.54 & 0.98 & A & 2.93 & 1.05 & A & 2.74 & 1.02 & A & 3.793 & 0.000 & S \\
\hline $\begin{array}{l}\text { 12. Sand filling water logged area to } \\
\text { reclaim lost land }\end{array}$ & 2.28 & 1.14 & $\mathrm{D}$ & 2.65 & 1.16 & A & 2.47 & 1.15 & $\mathrm{D}$ & 1.947 & 0.058 & NS \\
\hline $\begin{array}{l}\text { 13. Switching to intensive management } \\
\text { of livestock }\end{array}$ & 2.72 & 0.90 & A & 3.20 & 0.79 & A & 2.96 & 0.85 & A & 5.507 & 0.000 & $\mathrm{~S}$ \\
\hline $\begin{array}{l}\text { 14. Skipping storage to processing and } \\
\text { marketing immediately affect harvest }\end{array}$ & 2.95 & 1.05 & A & 3.33 & 0.93 & A & 3.14 & 0.99 & A & 3.882 & 0.000 & S \\
\hline $\begin{array}{l}\text { 15. Changing from production of } \\
\text { agriculture to marketing }\end{array}$ & 2.29 & 0.99 & $\mathrm{D}$ & 3.02 & 1.14 & A & 2.66 & 1.07 & A & 6.794 & 0.000 & S \\
\hline $\begin{array}{l}\text { 16. Sinking of boreholes in farm to } \\
\text { ensure water availability/artificial } \\
\text { irrigation }\end{array}$ & 2.12 & 1.18 & $\mathrm{D}$ & 3.13 & 1.07 & A & 2.63 & 1.13 & A & 6.234 & 0.000 & S \\
\hline $\begin{array}{l}\text { 17. Collection of runoff water in ditches } \\
\text { for drought periods }\end{array}$ & 2.92 & 1.01 & A & 3.05 & 1.28 & A & 2.99 & 1.15 & A & 9.658 & 0.000 & S \\
\hline $\begin{array}{l}\text { 18. Switching to fish farming rather } \\
\text { than fishing }\end{array}$ & 2.77 & 0.91 & A & 3.06 & 1.11 & A & 2.92 & 1.01 & A & 3.058 & 0.002 & $S$ \\
\hline $\begin{array}{l}\text { 19. Construction of foot bridges with } \\
\text { wood, stones and sand bags }\end{array}$ & 3.62 & 1.04 & SA & 2.75 & 1.27 & A & 3.19 & 1.16 & A & -1.986 & 0.024 & S \\
\hline $\begin{array}{l}\text { 20. Raising walls with sand bags and/or } \\
\text { blocks to divert flood water }\end{array}$ & 3.51 & 0.71 & SA & 3.81 & 0.98 & SA & 3.66 & 0.85 & SA & 1.551 & 0.112 & NS \\
\hline $\begin{array}{l}\text { 21. Construction of drainage system or } \\
\text { dam within farm/household }\end{array}$ & 2.75 & 0.90 & A & 2.89 & 1.17 & A & 2.82 & 1.04 & A & 1.831 & 0.052 & NS \\
\hline $\begin{array}{l}\text { 22. Establishment and creation of food } \\
\text { grain reserves at farm and } \\
\text { community levels for safe-keeping } \\
\text { and storage of harvested produce }\end{array}$ & 3.01 & 0.87 & A & 2.86 & 0.91 & A & 2.94 & 0.89 & A & 3.422 & 0.051 & NS \\
\hline $\begin{array}{l}\text { 23. Subsidizing of agricultural inputs by } \\
\text { relevant authorities }\end{array}$ & 3.38 & 0.86 & A & 3.23 & 0.83 & A & 3.31 & 0.85 & A & -1.605 & 0.076 & NS \\
\hline $\begin{array}{l}\text { 24. Setting up of housing programmes } \\
\text { for displaced farmers }\end{array}$ & 2.61 & 0.92 & A & 2.96 & 1.11 & A & 2.79 & 1.02 & A & 3.604 & 0.000 & S \\
\hline $\begin{array}{l}\text { 25. Resettlement of communities from } \\
\text { hazard zones }\end{array}$ & 2.59 & 0.98 & A & 3.18 & 0.91 & A & 2.89 & 0.95 & A & 3.627 & 0.000 & $\mathrm{~S}$ \\
\hline $\begin{array}{l}\text { 26. Giving the affected farmers financial } \\
\text { support }\end{array}$ & 3.18 & 0.99 & A & 3.27 & 0.88 & A & 3.25 & 0.94 & A & 1.229 & 0.207 & NS \\
\hline 27. Vaccinating against diseases & 3.02 & 1.08 & A & 3.16 & 0.82 & A & 3.09 & 0.95 & A & 1.912 & 0.046 & $\mathrm{~S}$ \\
\hline 28. Change profession entirely & 1.76 & 1.06 & $\mathrm{D}$ & 2.92 & 1.24 & A & 2.34 & 1.15 & $\mathrm{D}$ & -1.713 & 0.068 & NS \\
\hline Cluster Value & 2.77 & 0.99 & A & 3.14 & 0.98 & $\mathbf{A}$ & 3.01 & 0.96 & A & 3.198 & 0.038 & $\mathbf{S}$ \\
\hline
\end{tabular}

Note: Dec—Decision; Avg. Resp.—Average Response; Strongly Agreed (SA = 3.50 - 4.00); Agreed (A = 2.50 - 3.49 ); Disagreed (D = 1.50 - 2.49); Strongly Disagreed (SD = 0.50 - 1.49); $\mathrm{p}=$ *Sig (2-tailed); R—Remark; NS—Non Significant; S—Significant. 
The standard deviation of all the items responded to by farmers ranged from $0.71-1.18$; indicating that the farmers were not far from the mean and from one another in their responses. While that of the extension workers ranged from 0.79 to 1.29 ; indicating that the extension workers were not far from their means and from one another in their responses.

The information from the structured interview complemented the data from the questionnaire as presented on Table 2. The most suggested practices for coping with climate change impacts such as sea level rise leading to coastal flooding included construction of foot bridges as well as raising walls with sand bags and/or blocks to divert flood water. Most of the respondents suggested giving of financial support to the affected farmers as well as subsidizing agricultural inputs by relevant authorities to encourage the farmers. Changing planting/harvesting period and mix cropping/farming were also suggested as coping strategies. Majority of the farmers mentioned appropriate medical checkup and vaccination against diseases which could be sponsored by the government to improve the general health and performance of the farming communities.

\subsection{Hypothesis 2}

Data presented on Table 2 revealed that there is significant difference (S) in the opinions of farmers and extension workers in eighteen items (No. 3 - 7, 9 - 11, 13 - 19, 24, 25 and 27) and a non-significant (NS) difference in ten items (No. 1, 2, 8, 12, 20 - 23, 26 and 28). The cluster value indicated that there is significant difference (S) in their opinions. Thus the null hypothesis of no significant difference of the items with remark NS was upheld as $p$-value is greater than the $a$-value ( $p \geq a$ ) at the t-calculated value of the items.

At the cluster level, $p=0.038$ and $t=3.198$ while $a=0.05$. T-test has indicated a statistically reliable difference in the opinions of the respondent farmers and extension workers. Thus the null hypothesis $\left(\mathrm{H}_{02}\right)$ of no significant difference is rejected as $p \leq a$.

\section{Discussion}

\subsection{Extent of Impacts of Climate Change on Farmers and the Farming Families in the Niger Delta Region of Nigeria}

Niger Delta like most coastal low lying regions of the world is constantly faced with flooding of various degrees. However, due to increased and varying extent of precipitation attributable to climate change, the occurrence of flooding has increased with rivers and oceans easily overflowing their banks. This was observed in the 2012 flooding that impacted negatively on agriculture in the region. The flood ravaged farmlands, storage buildings and farmers houses. Climate change seems to have impacted to a low extent on water availability for irrigation as well as drying up of ponds and streams. This finding is true to the region as artificial irrigation is seldom practiced and increased precipitation has ensured constant supply of water to ponds and streams. This view is supported by [2] [9] who stated that increased precipitation will cause excess of water. As stated, wet regions will receive more rain while dry regions will become even drier. Increase in mortality rate tied directly to climate change in the region was not indicated by the respondents. This finding disagrees with [16] who stated that there will be increased death rate due to factors favoured by climate change.

Climate change has impacted negatively but moderately on most farming families though with some farmers reporting that the extent of impact is slightly high on cost of production (input and labour cost) as well as on net profit from farming thus impacting on poverty level of farmers in the region. This finding is in agreement with that of [9] [28] [29] that stated that difficulty on farm operations and cost of agricultural production will increase with decreasing returns to the farmer.

Findings of the study revealed that significant difference does not exist between the mean responses of the farmers and the extension workers on the perceived impacts of climate change on farmers and the farming families in the region, as indicated by t-test. Any observed difference is not a statistical difference, but a mere chance which could have resulted from sampling error.

\subsection{Strategies That Can Be Adopted to Alleviate the Impacts of Climate Change on Agricultural Production to Favour the Farmer and the Farming Families in the Niger Delta Region of Nigeria}

The farmers and the extension workers strongly agreed to construction of foot bridges with wood, stones and 
sand bags as a coping strategy mainly due to its affordability and suitability and not waiting for government and foreign aid. This strategy is really in use in the region to divert flood water and create walk ways.

The respondents disagreed with planting deeper than the usual planting depth as a coping strategy likely due to the specified planting depth for various crops. If the depth is increased beyond the required, the plants may not germinate well (and die in the ground suffering the same fate as scorched germination) or results to scanty germination as some of the seedlings may not successfully pass through the increased depth to germinate. Sand filling water logged area to reclaim lost land seems to be an expensive and tedious practice as a coping strategy for an indigent farmer. Trips of sand to fill the vast water logged area could cost the farmer a fortune he may not be able to afford. This is the explanation given by majority of the respondents as to why they disagreed with this option as a coping strategy. For changing profession entirely, most farmers interviewed revealed that "farming is all they know and for the elderly, it is already late to change profession”.

The farmers disagreed to changing from production of agriculture to marketing due to the vital role of local farmers as producers. On further inquiry using the interview, the farmers simply reply "if everyone switches to marketing, who will do the production for supplies to be marketed?” For artificial irrigation as an alleviating strategy, most farmers in the region are too poor to own boreholes in their farms. The region being a coastal one does record high occasion of rainfall in a planting cycle. This was explained as the reason why most crop farmers in the region practice rain-fed agriculture. This view is supported by [9] who stated that the abundant rainfall in the region favours rain-fed agriculture.

The farmers and the extension workers agreed to most of the suggested coping strategies. These findings are favoured by the views of many authors such as [3] [9] [23] [26]-[28] who suggested the adaptive measures against climate change as contained in their respective works.

The opinion of the farmers and the extension workers is at variance with each other, may be due to varying degree of education, awareness and experience in farming as well as their geographical location.

\section{Conclusions}

Findings of this study served as a premise for making the following conclusions:

- The perceived extent of impacts of climate change on farmers and the farming families in the region were moderate.

- The opinion of the farmers and the extension workers on the perceived impacts of climate change on farmers and the farming families in the region is similar for extent of impacts but differ for coping strategies.

- Flood is a major threat to sustainable agriculture and livelihood in the region.

- Poverty level is on the rise as a result of low net profit from agriculture caused by the negative impacts of climate change in the region.

\section{Implications of the Findings}

The results of this study have provided empirical evidence of the extent of impacts of climate change on farmers and the farming families in the Niger Delta region of Nigeria, and it is moderate. This will provide guide to the government and relevant authorities on the extent of help and information to be giving to the farmers to encourage production in the region. Most of the farmers reported that poverty level is on the rise. There is therefore the need for the government to re-assess the poverty level in the region or the country at large to provide current index.

Opinion of the farmers and the extension workers is at variance with each other on coping strategies. This is an indication that the farmers and the extension workers are information apart thus requiring re-orientation of the farmers and/or the extension workers in the region to generate and spread unified, teachable and adoptable strategies to combat the felt impacts of climate change in the region, in Nigeria and beyond.

\section{Recommendations}

Based on the findings of this study, the following recommendations have been proffered:

- Extension workers should be continuously trained and educated on current information about climate change and sent out to enlighten the farmers. This will enable them to update and synchronize ideas and strategies with the farmers. 
- Farmers in the region should be encouraged by providing incentives and subsidizing inputs for them by Federal and State government as well as other non-governmental organizations. This will go a long way in improving production especially as most farmers agree to continue cultivation even with the observed impacts.

- Most crop farmers in the region practice rain-fed agriculture. With the altered rainfall pattern the farmers are unable to effectively predict the trend. Thus it is necessary for the government and other relevant authorities to constantly provide weather information such as rainfall distribution ahead of time to help the farmers plan. The information can be made available and updated through the extension workers, radio and/or television broadcasts.

\section{References}

[1] Federal Ministry of Agriculture and Rural Development (2012) Nigeria’s Key GDP Contributors. Federal Bureau of Statistics, Federal Republic of Nigeria.

[2] Lemke, P. (2006) Synthesis Report. Alfred Wegener Institute of Polar and Marine Science. http://www.grida.no/climate/ipcc_tar/wg1/518.htm

[3] Intergovernmental Panel on Climate Change (2007) Impacts, Adaptation and Vulnerability. Summary for Policymakers, in Climate Change: Contribution of Working Group II to the Fourth Assessment Report Cambridge. Cambridge University Press. http://www.ipcc.ch/pdf/assessment-report/ar4/syr/ar4_syr_spm.pdf

[4] Ugolor, D. (2004) Oil of Poverty in the Niger Delta. African Network for Environment and Economic Justice, 24, 243348.

[5] Fapojuwo, O.E., Ajayi, M.T. and Abiona, B.G. (2012) The Roles of Agricultural Education and Training in Nigerian Graduates Employment Situation. University of Agriculture, Abeokuta.

[6] Aweto, A. O. (2011) Agriculture in Urhoboland. http://www.waado.org/geography/Agriculture/Agruclture-Aweto.html

[7] Rosemary, N.O., Okoh, P.N., Michael, I., Ajibefun, I.A., Idehen, K.I., Ajieh, P.C. and Osakwuni, E.U. (2012) Assessment of Impacts, Vulnerability, Adaptive Capacity and Adaptation to Climate Change in the Niger Delta Area, Nigeria. http://rurallinkage.net/project_details.php?project_id=3\&pix_id=4\&category_id=2

[8] Abisola, A. (2013) Where Cultivation Meets Conflict: Farming in the Niger Delta. Nourishing the Planet. http://blogs.worldwatch.org/nourishingtheplanet/where-cultivation-meets-conflict-farming-in-the-niger-delta/

[9] Uyigue, E. and Agho, M. (2007) Coping with Climate Change and Environmental Degradation in the Niger Delta of Southern Nigeria. Community Research and Development Centre (CREDC), Benin, Nigeria. CREDC Press, Benin.

[10] Engber, D. (2006) How Gasoline Becomes $\mathrm{CO}_{2}$. Slate Magazine. m www.slate.com

[11] The Guardian (2012) World Carbon Emissions: The League Table of Every Country. http://m.guardian.co.uk/environment/datablog/2012/jun/21/world-carbon-emissions-league-table-country

[12] Akinro, A.O., Opeyemi, D.A. and Ologunagba, I.B. (2008) Climate Change and Environmental Degradation in the Niger Delta Area of Nigeria: Its Vulnerability, Impacts and Possible Mitigations. Research Journal of Applied Sciences, 3, 167-173.

[13] World Bank (2008) World Bank Development Report: Agriculture for Development. Washington DC.

[14] Olurin, T.A. and Agbola, T. (2003) Land Use and Land Cover Change in the Niger Delta. Centre for Democracy and Development, Nigeria.

[15] Ogundele, B. (2012) Flood Disasters Will Be Greatest Humanitarian Crisis after Civil War as Flood Sacks More Rivers’ Communities. Nigerian Tribune. www.nigeriantribune.com

[16] Cruz, R.V., Harasawa, H., Lal, M., Wu, S., Anokhin, Y., Punsalmaa, B., Honda, Y., Jafari, M., Li, C. and Huu Ninh, N. (2007) Asia. In: Parry, M.L., Canziani, O.F., Palutikof, J.P., van der Linden, P.J. and Hanson, C.E., Eds., Climate Change 2007: Impacts, Adaptation and Vulnerability, Contribution of Working Group II to the Fourth Assessment Report of the Intergovernmental Panel on Climate Change, Cambridge University Press, Cambridge, UK, 469-506.

[17] Magrin, G., Gay García, C., Cruz Choque, D., Giménez, J.C., Moreno, A.R., Nagy, G.J., Nobre, C. and Villamizar, A. (2007) Latin America. In: Parry, M.L., Canziani, O.F., Palutikof, J.P., van der Linden, P.J. and Hanson, C.E., Eds., Climate Change 2007: Impacts, Adaptation and Vulnerability, Contribution of Working Group II to the Fourth Assessment Report of the Intergovernmental Panel on Climate Change, Cambridge University Press, Cambridge, UK, 581-615.

[18] Myers, N. (2005) Environmental Refugees: An Emergent Security Issue. 13th Economic Forum, Prague, 23-27 May 2005, 23-27.

[19] Mimura, N., Nurse, L., McLean, R.F., Agard, J., Briguglio, L., Lefale, P., Payet, R. and Sem, G. (2007) Small Islands. In: Parry, M.L., Canziani, O.F., Palutikof, J.P., van der Linden, P.J. and Hanson, C.E., Eds., Climate Change 2007: 
Impacts, Adaptation and Vulnerability, Contribution of Working Group II to the Fourth Assessment Report of the Intergovernmental Panel on Climate Change, Cambridge University Press, Cambridge, UK, 687-716

[20] Boko, M., Niang, I., Nyong, A., Vogel, C., Githeko, A., Medany, M., Osman-Elasha, B., Tabo, R. and Yanda, P. (2007) Africa. In: Parry, M.L., Canziani, O.F., Palutikof, J.P., van der Linden, P.J. and Hanson, C.E., Eds., Climate Change 2007: Impacts, Adaptation and Vulnerability, Contribution of Working Group II to the Fourth Assessment Report of the Intergovernmental Panel on Climate Change, Cambridge University Press, Cambridge, UK, 433-467.

[21] Hassan, A. (2012) Nigeria: Floods - Country Shall Not Have Food Crises or Famine. www.allafrica.com

[22] Idowu, A.A., Ayoola, S.O., Opele, A.I. and Ikenweiwe, N.B. (2011) Impact of Climate Change in Nigeria. Iranica Journal of Energy \& Environment, 2, 145-152.

[23] Apata, T.G. (2010) Effects of Global Climate Change on Nigerian Agriculture: An Empirical Analysis. CBN Journal of Applied Statistics, 2, 31-50.

[24] Intergovernmental Panel on Climate Change (2001) Impact, Adaptation and Vulnerability. Contribution of Working Group II to the Third Assessment Report of IPCC. University Press, Cambridge.

[25] Newton, C., Paci, D. and Ogden, A.E. (2005) Climate Change Adaptation and Regional Forest Planning in Southern Yukon, Canada. Mitigation and Adaptation Strategies for Global Change, 13, 833-861.

[26] Wolfe, D.W. (2007) Climate Change Impacts on Northeast Agriculture. Department of Horticulture, Cornell University, Ithaca, New York.

[27] Chakeredza, S., Temu, A.B., Yaye, A., Mukingwa, S. and Saka, J.D. (2009) Mainstreaming Climate Change into Agricultural Education: Challenges and Perspectives. ICRAF Working Paper No. 82. World Agroforestry Centre, Nairobi.

[28] Bhusal, Y.R. (2009) Local Peoples’ Perceptions on Climate Change, Its Impacts and Adaptation Measures in MidMountain Area of Nepal (A Case Study from Kaski District). Unpublished. Forestry Research Thesis Submitted to Tribhubhan University, Institute of Forestry, Pokhara.

[29] Miguel, A.A. and Koohafkan, P. (2010) Impacts of Climate Change on Traditional Family Farming Communities. Oxford University Press, New York.

\section{Appendix A}

Distribution of the Respondents $(n=2922)$.

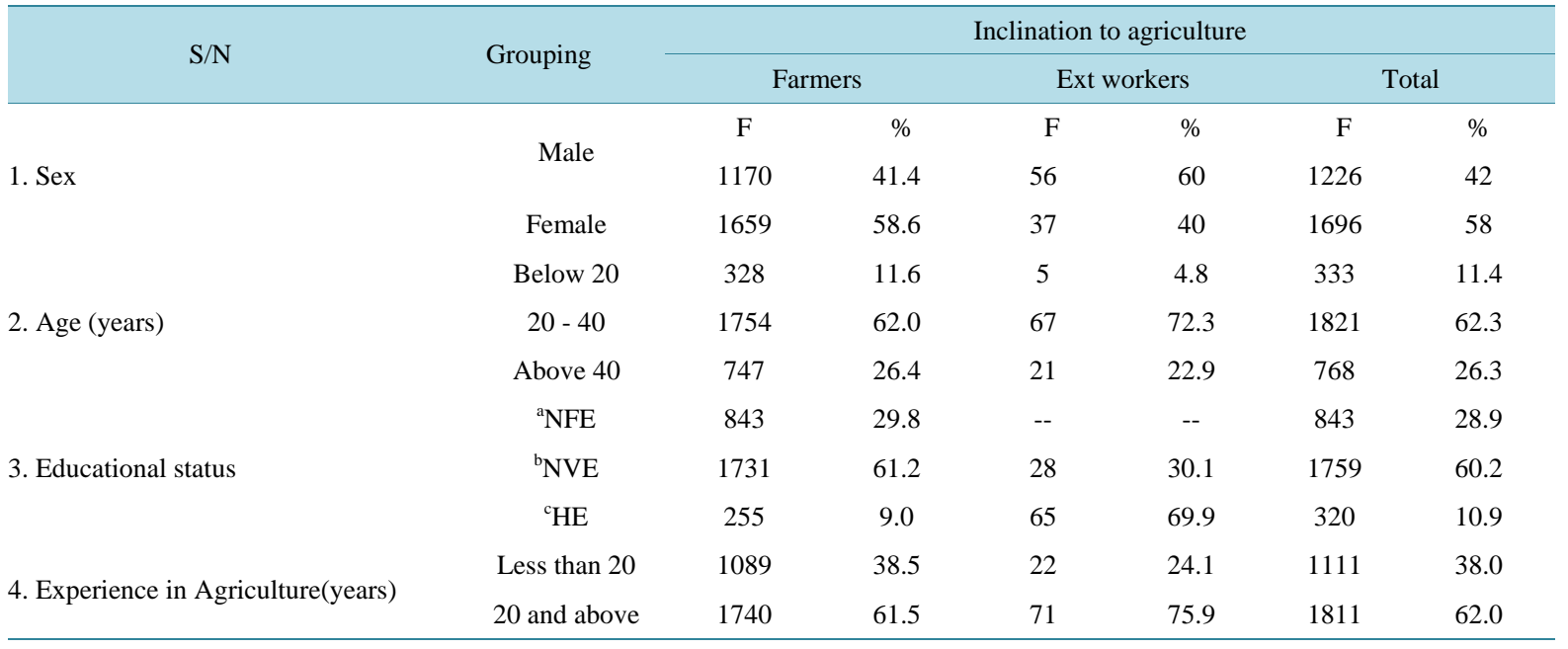

Note: $\mathrm{a}$ = No Formal Education; $\mathrm{b}$ = Not Very Educated; $\mathrm{c}=$ Higher Education. 
Scientific Research Publishing (SCIRP) is one of the largest Open Access journal publishers. It is currently publishing more than 200 open access, online, peer-reviewed journals covering a wide range of academic disciplines. SCIRP serves the worldwide academic communities and contributes to the progress and application of science with its publication.

Other selected journals from SCIRP are listed as below. Submit your manuscript to us via either submit@scirp.org or Online Submission Portal.
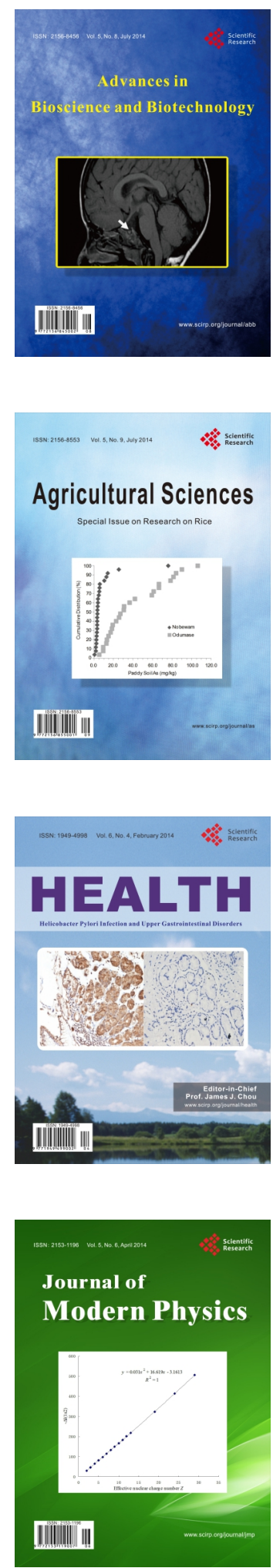
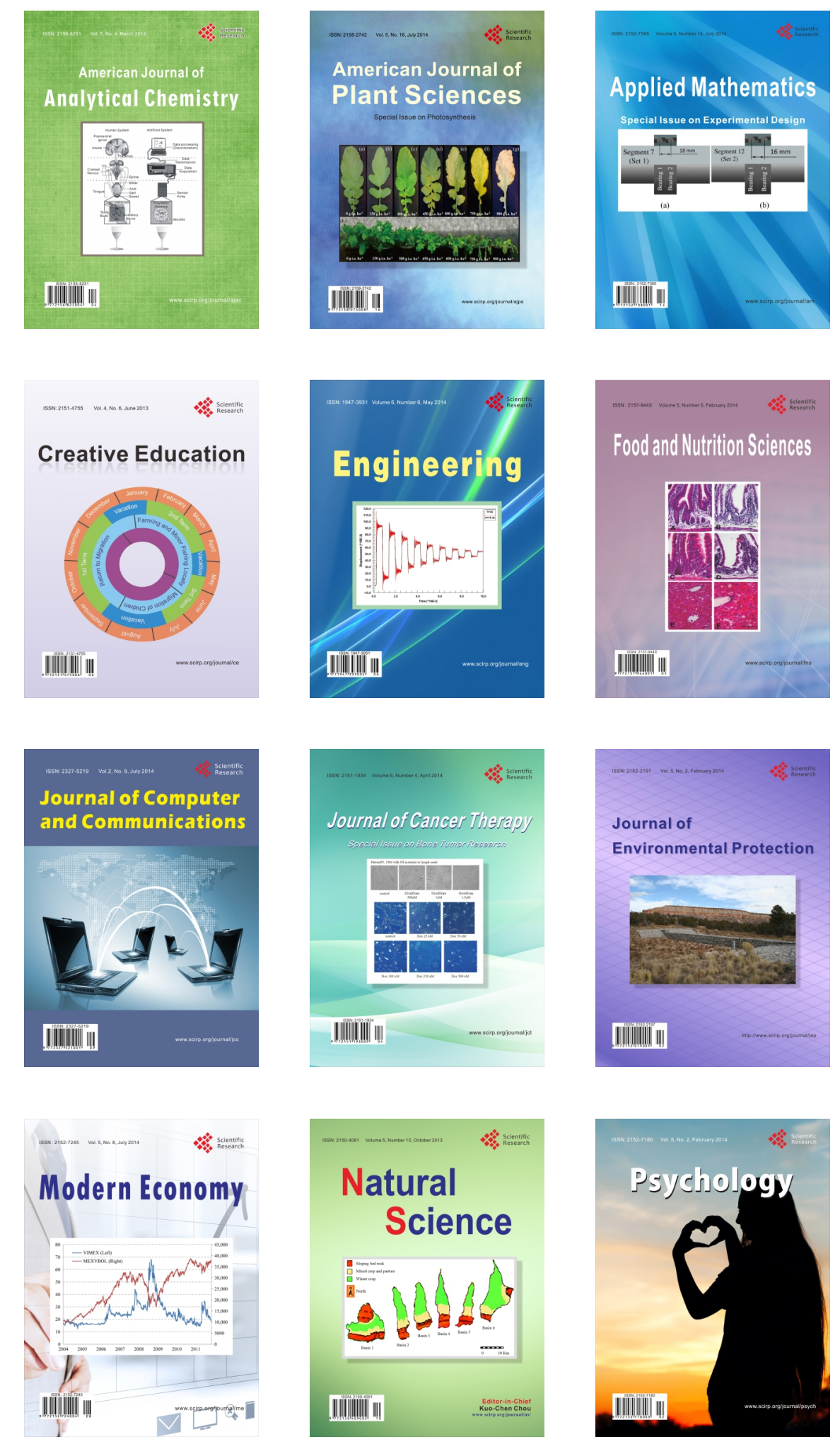